\title{
Expressive Writing in Minimizing Students' Public Speaking Anxiety
}

\author{
F. Tresnawati, B. Musthafa \\ Universitas Pendidikan Indonesia \\ Bandung, INDONESIA
}

\begin{abstract}
Many students of EFL find it difficult to deliver their ideas in front of audiences, eventhough they have capabilities to do that. It is found that the commonest problem comes from the students themselves, such as lack of confidence and fright of making mistakes. Therefore, students' anxieties to speak in front of audience is considered as an emergency issue in teaching EFL in Indonesia. Related to this probem, this study attempts to observe (1) what factors cause students' public speaking anxiety in EFL context, (2) how expressive writing helps students in minimizing their public speaking anxiety, and (3) observe the benefits and challenges for students in doing expressive writing. The data in this study were collected through observation, document analysis, and interview, then they were analyzed qualitatively. This study was undertaken in one university in Bandung. Four participants were selected purposively based on certain criteria. After all, it is found that there are four factors that might cause the students' speaking anxiety, namely lack of confidence, lack of vocabulary, fear of failure, and fear of negative evaluation. Regarding the benefits and challenges of expressive writing in minimizing students speaking anxiety, it is found that expressive writing helps students to have better speaking performance, lower level of public speaking anxiety, and better mental especially in emotion management, stress management, and problem solving. However, it is also found that the students have difficulties in encouraging themselves to keep on writing during the sessions of expressive writing, moreover, students need more efforts at the beginning of the expressive writing sessions.
\end{abstract}

Keywords - public speaking anxiety, expressive writing

\section{INTRODUCTION}

In recent years, speaking is believed as the basic skill of language learning and the most demanding skill for many English as Second Language (ESL) or English as Foreign Language (EFL) students. This is due to the fact that most of language learners tend to focus on how much they have improved their speaking skill as parameter of their language learning effectiveness as well as its success (Richards, 2008: 19). In line with this, Widiati \& Cahyono (2006: 269) also state that large number of students want to study English in order to be able to use English for communicative purposive. Therefore, it can be said that students' success or lack of success in ESL or EFL is judged by the accuracy of the language they produced. Concerning in speaking skill, Nunan (1991) asserts that for most of people, mastering the art of speaking is the single most important aspect of ESL or EFL, and success is measured in terms of the ability to carry out a conversation in the language.
Speaking is a tool for communicating with people, through speaking we can share our idea and knowledge. In fact, many students in Indonesia are afraid of speaking in public. This is supported by Lengkanawati (2004) who says that eventhough many people now are not hesitant to speak up, this kind of behaviour has not fully been reflected in language classroom. This is in line with Harmer (2004: 345), that students are often reluctant to speak because they are shy and not predisposed to express themselves in front of people, especially when they are being asked to give personal information or opinion. Frequently, too, there is a worry about speaking badly and loosing face in front of their classmates. Moreover, Based on a study conducted by Putra (2004) on students performing in public speaking of English shows that the students have got mental problems such a fright of making mistake. Moreover, according to research conducted by McCroskey (1989), there are 15-20\% of students in United States have communication anxiety. In line with this, Anwar (2009) adds that $16,3 \%$ of students in University of North Sumatera are having high level of public speaking anxiety. Katz (2000) believes that public speaking anxiety is very common among students. His research shows that $20 \%$ to $85 \%$ of students experience anxiety when they speak in public. Susanti (2013) adds that anxiety of public speaking has a negative impact on academic performance, such as the lack of involvement in class discussion and the excessive fright in doing presentation.

Adrianto and Goddess (2006) conducted research on the relationship between public speaking anxiety and students' perception of capabilities (confidence), the result shows that better perception leads to lower levels of anxiety, vice versa. Ratnasari (2009) adds that there is a positive relationship between self-confidence and interpersonal communication skills, people who have high confidence tend to have good communication skills. They are able to overcome fears or negative thoughts about themselves and others, thus they communicate well.

From the explaination above, it is found that the main problem faced by students in speaking is the students' confidence themselves. Moreover, many previous studies have investigated language anxiety, and most of them find that emotional factor is the main cause of the public speaking anxiety. Many students are afraid of speaking up in front of audiences even though they have many ideas to be shared. Therefore, it is realized that students' public speaking anxiety is emergency issue in teaching EFL in Indonesia.Therefore, as a teacher, we should provide activities that give opportunities to students to practice speaking a lot in the classroom. Not only the appropriate 
learning strategy, but also it needs a kind of treatment that helps students to cope their public speaking anxiety and improve their confidence to do public speaking.

One kind of activity that may help students to cope with public speaking anxiety is expressive writing (Bolton, 2011). Expressive writing is a term for something very simple: expressing yourself through writing. It is the process of putting thoughts, feelings and experiences into words. Expressive writing is what you are doing when you write in a journal or a diary. Generally, expressive writing is a private and guided writing exercise designed to improve creativity and self-confidence; strengthen interpersonal communication skill; help to express the emotions; and improve problem solving and individual adaptive skill (Gorelick, in Malchiodi: 2007). Moreover, Pennebaker (1989, Pennebaker \& Chung, 2011) defines expressive writing as a process of writing one's deepest thoughts and feeling about troubles. Moreover, Sanousi (2004) adds that expressive writing is a way of using writing to gain insight into personal struggles and to heal emotional wounds. Writing can also be a self-healing therapy when we rely on ourselves to develop personally, heal our physiological wounds, understand our needs, and explore our creativity.

In Indonesia, there are several studies focus on the efficiency of expressive writing in several context. Susilowati (2009), Qonitatin, Widyawati, and Asih (2011) observed the effect of expressive writing towards students' minor depression. Moreover, Fikri (2012) finds that expressive writing helps male teenagers in managing their negative emotion. In line with this current study, Susanti (2013) conducted a research on the influence of expressive writing therapy to reduce public speaking anxiety of college students. She finds that after expressive writing sessions, students have lower level of public speaking anxiety. The decrease of level of public speaking anxiety covers three aspects; they are physic, mental, and emotions. She adds that after doing expressive writing session, students have better self-esteem and sense of well-being.

Based on the issues above, the writer of this study believes that expressive writing activities give several benefits related to students in manage their anxiety in doing public speaking although it is in EFL context. Therefore, this study attempts to observe what factors cause students' public speaking anxiety in EFL context, how expressive writing help students in minimizing their public speaking anxiety, and observe the benefits and challenges for students in doing expressive writing for minimizing their anxiety of public speaking.

Related to the explanation above, this study focuses on the following questions:

- What factors are causing students' public speaking anxiety in EFL context?

- How is expressive writing implemented in order to minimize students' public speaking anxiety?

- What are benefits and challenges in doing expressive writing for students?

\section{RESEARCH METHOD}

This research is aimed at (1) observing what factors cause students' public speaking anxiety in EFL context, (2) observing how expressive writing activities are implemented (3) observing the benefits and challenges for students in doing expressive writing for their public speaking performance. To investigate this kind of research, a qualitative method research was conducted.

Qualitative approach is used to comprehend social phenomenon from participant point of view which has two main objectives: 1. to describe and explore; 2 . to describe and explain (Sukmadinata, 2011: 72). Referring to the research questions, this study is conducted to describe, explore, and explain the whole phenomena occur during the process of presentation and expressive writing. Qualitative approach portrays any recurring phenomena in the observation field, describes them, reports and gives further analysis and elaboration as well as interpretation (Alwasilah, 2002).

In this study, a case study is conducted to gain in depth understanding of any phenomena occur during the process of expressive writing and students' presentation. This is supported by Merriam (1998: 19) who states that a case study is employed to gain an in depth understanding of the situation and meaning for those who involved; and that the interest is in process rather than outcomes. follows

Some procedures conducted to carry out this study as

a) Determining the background of the study. From the background, the problem and the purpose of the study were identified;

b) Finding out some theories and concept related to students' public speaking anxiety and expressive writing;

c) Selecting participants. This study was conducted in one university in Bandung, the participants were selected based on several criteria.

d) Collecting data through tests, interview, and document of students' writing;

e) Doing pre-observation in order to analyzed the level of students public speaking anxiety (test of anxiety level HAM-A);

f) Observing the expressive writing activities for six meetings and students presentations. Researcher wrote field notes;

g) Doing post-test of students' public speaking anxiety

h) Preparing interview guidelines;

i) Interviewing the participants to get more insight from their perspective related to public speaking anxiety and expressive writing;

j) Analyzing the obtained data;

k) Interpreting the findings, and linking them to relevant theories;

1) Drawing conclusion based on the findings and proposing a recommendation. 
This study was undertaken in one university in Bandung. They are selected purposively based on certain criteria (Sugiyono, 2010: 300). The participants are selected through these criteria:

- Students of English major in one university in Bandung

- Students who are familiar with English basic grammar

- Students who have to have presentation as their academic performances

- Students who have high level of anxiety in public speaking

- Students who are willing to be participant of this study

Participants in this study are 51 students of speaking class, majoring in English, in which they are familiar in Basic English grammar and they have to perform their speaking in front of the class. After the pre-test was administered, there are five students who have high level of anxiety, but only four of them who are willing to be involved in this study. Those four students were the main participants of this study.

This research uses three instruments to collect the data, namely observation, interview, and document analysis. As Scott and Usher (2011) explain that in a case study, the method of data collection function to capture the lived reality, which usually use observation, semistructured interview, and documentary analysis as the techniques.

After collecting data from the three research instruments, the researcher categorized the data based on the three research questions. The data from the observation were analyzed from the field notes to answer first, second, and third research questions. Field notes were used to get deeper comprehension of students' presentations and expressive writing activities. Moreover, the data from interview were used to add some information to answer the first research question related to the factors of their speaking anxiety; and third research questions related to benefits and challenges of expressive writing activities.

In addition, the data from the document analysis were taken from the test of anxiety level and the students' expressive writing products. They were used to support the findings that answer all of the research questions.

\section{FINDING AND DISCUSSION}

The data in this study were obtained from a series of tests of public speaking anxiety, observations and interviews. The observations were conducted to see students' expressive writing activities and improvement in speaking performance. It focused on students' anxiety that experienced by the students. Generally, there were 51 students in a speaking class who were taking the test of public speaking anxiety level (HAM-A by Hamilton (1959)). The result of the test can be seen in detail in the figure 1.

It can be seen from the chart above, that, although the percentage of high anxiety level gain the lowest percentage, it shows us that the speaking anxiety still become the problem that the students have to cope. The chart shows that $59 \%$ of the students experienced mild to moderate severity of anxiety in doing public speaking. Moreover, $10 \%$ of them are students who have high level of anxiety or moderate to severe of speaking anxiety.

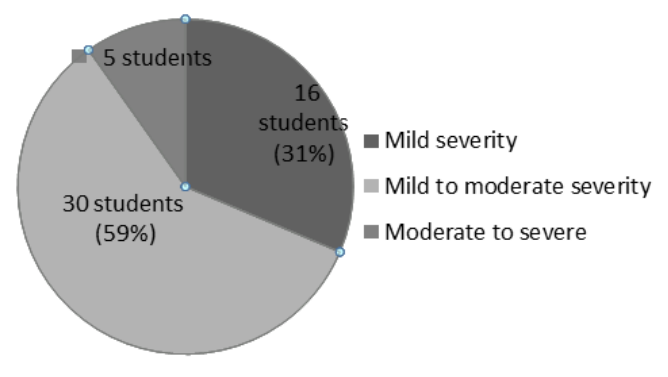

Fig. 1. Public Speaking Anxiety Level

Then, those four students are fully involved in this study as the participants. The four participants are described below:

First participant (P\#1). From the test of anxiety level, she got 27 score that indicated she had moderate to severe of speaking anxiety. She admitted that before the time of speaking assignment, she had to face the nightmares, sleepless night and waking up in uncomfortable condition. She tended to have uncontrolled mood. On the day of the assignment, it was hard for her to concentrate on the materials that she had to be presented, and she felt faint. In terms of speaking performance, she seemed difficult to understand and had a hard time communicating her ideas and responses because of grammar mistakes. She seemed difficult to understand, quiet in speaking, unclear in pronunciation. She had inadequate vocabulary words to express her ideas properly, which hindered the students in responding. She had a difficulty of understanding the questions and topics that were being discussed. Speech was very slow, stumbling, nervous, and uncertain with response, except for short or memorized expressions. It was difficult for a listener to understand. Based on the teacher in the class, she tended to keep silent during teaching learning process, and every time the teacher asked for her opinion or answer, she had hard time to deliver her idea.

Second participant (P\#2). After having test of anxiety level, she got 25 of the score that included her to have moderate to severe of speaking anxiety. At the time of facing a presentation, she felt nervous, easily startled, easy to cry, lethargy, trembling and restless. She was also scared to face the crowds and afraid to be left alone. She felt the heart beats rapidly and weak, dry mouth, easy to sweat, the head feels heavy and creeps. She was very tense and agitated forehead wrinkle and facial muscles tense. In terms of speaking performance, she was able to express her ideas and responses fairly well but made mistakes with her tenses; however, she was able to correct them. Pronunciation was good and did not interfere with communication. She utilized the words learned in class, in an accurate manner for the situation given. She was able to comprehend and respond to most of the questions and topics that were being discussed. Speech was mostly smooth but with some hesitation and unevenness caused primarily by rephrasing and groping for words. 
Third participant (P\#3). She got 54 score that indicated she had seriously severe level of anxiety. In every item that being asked in the test of anxiety level, she admitted that she felt very severe symptoms, such as anxiety, feeling bad, irritable, tense, trembling, afraid to be left alone, nightmares, waking at night, difficulty concentrating, decreased memory, feelings change, muscle pain, hoarseness and unstable, pale, feel weak, fast heart beats, shortness, palms cold, dry mouth, easy sweating, heavy fist, forehead wrinkle. In term of speaking performance, she seemed difficult to understand and had a hard time in communicating her ideas and responses because of grammar mistakes. She seemed difficult to understand, quiet in speaking, unclear in pronunciation. She had inadequate vocabulary words to express her ideas properly, which hindered the students in responding. She had difficulty for understanding the questions and topics that were being discussed. Speech was very slow, stumbling, nervous, and uncertain with response, except for short or memorized expressions.

Fourth participant (P\#4). From the test of anxiety level, he got 25 score that indicated he had moderate to severe of speaking anxiety. He admitted that before the time of speaking assignment, he had feeling bad, irritable, tense, trembling, fast heart beats, shortness breathe. In terms of speaking performance, he was able to express his ideas and responses adequately but often displayed inconsistencies with his sentence structures and tenses. He was slightly unclear with pronunciation at times, but generally was fair. He was able to use broad vocabulary words but was lacking, making his repetitive and cannot expand on his ideas. She fairly grasped some of the questions and topics that were being discussed. Speech was slow and often hesitant and irregular. Sentences may be left uncompleted, but he was able to continue.

Therefore, the discussion below is about the factors might cause their public speaking anxieties, the description of expressive writing process -as one of alternatives in coping students' public speaking anxietyin minimizing their speaking anxiety, and the benefits and challenges in employing expressive writing toward their speaking anxiety. The discussion is presented based on the research questions used in this study.

\section{FACTORS CAUSE STUDENTS' PUBLIC SPEAKING ANXIETY}

\section{Lack of Confidence and Shyness}

Inability to express the idea because of lack of selfconfidence is one of the commonest causes of anxiety of speaking EFL. Students' lack of confidence in speaking EFL usually occurs when they think that they do not have good language competence of EFL.

In addition, shyness also inhibits the speaker to be confident to speak in front of the audience. Juhana (2010: 20) argues that speaking EFL in front of people is one of the more common phobias that the students encounter, and feeling of shyness makes their mind go "blank" or forget what to say. This theory also supported by the result of the research by Liu (2007), he finds that when students feel shy and nervous during the presentation, they cannot say any words and they have forgotten all the words they learnt.
Many people simply lack the confidence in their ability to face the audience. They believe they do not have the skills and ability to speak publicly. Therefore, when they find themselves standing before an audience, this lack of confidence only creates a vacuum that is filled by public speaking anxiety. The lack of confidence itself is usually followed by feeling nervous extremely. Students are afraid of something which is not real then block themselves to speak.

Similarly, Harmer (2004) also adds that students are often reluctant to speak because they are shy and are not predisposed to expressing themselves in front of people, especially when they are shy and are being asked to give personal information or opinion. As the result, some students kept on trying in speaking English in spite of their imperfect ability and irregular errors, but the others did all potential to stay away from speaking in English.

\section{Lack of Vocabulary}

Vocabulary is the smallest thing must be mastered to be able to speak. Lack of vocabularies of target language leads students' difficulties in delivering their ideas. Lack of vocabulary tends to be one of the well-known sources of foreign language anxiety. In fact, students confessed that lack of vocabulary is their flaw and became an immense barrier for them to bear their ideas in English.

A research conducted by Togatorup (2009) supports the finding, it shows that the main cause of the students' speaking obstacle are students themselves (limitation in vocabulary and grammar), therefore, realizing their limitation, students got afraid of making mistakes. In line with this, it can be believed that lack of vocabulary was recognized as a reason for students' anxiety in English speaking, as it can guide to the students' difficulties in language response and production and turn into obstacles that hinder them to speak their mind.

\section{Fear of Failure}

Fear of failure often place students in unrealistic demands on themselves. Fear of failure is assumed to be one of the most significant parts of negative drive. It can be defined as "unpleasant feeling or emotional state that has physiological and behavioral concomitants and that is experienced in formal testing or other evaluative situations" (Dusek, 1980 in Cubukcu, 2007).

A little tenseness can, in fact, facilitate students act upon their best. Yet, when this distress becomes too much it may actually hinder the performance on a test. Moreover, particularly it does not signify that the students are incapable to speak English. They prepare and know how to speak, but the fear of doing badly or even failure takes them into a psychologically condition that stop them to demonstrate their factual potential and ability.

\section{Fear of Negative Evaluation}

This is one of the most frequently cited causes of public speaking fears. Such feelings are natural as none wants to be negatively evaluated. Everyone wants to be seen good by those whom considered important. As a result, whenever people are faced with the prospect of giving a speech, they are immediately hit by thoughts of how they can create a good impression of themselves. The mind also starts worrying about how the listeners will 
perceive and appraise the presentation. With this in mind, instead of concentrating on the task at hand, many of them allow themselves to be enveloped by all sorts of imaginable fears. They fear that the audience may dislike the presentation. They fear that they may just disappoint themselves and others. All these 'wagging war' in their heads naturally lead to nervousness. This is understandable because all of them have worked hard to create an image of ourselves. And instead of ruining that image, most of us rather prefer to keep shut, sit down and watch others do the talking. It is all because of fear of negative evaluation. Fear of negative evaluation is the factor sourced from the people and surroundings outside the students. It may occur in any situation. Students may be sensitive to the evaluations of their peers. In case of foreign language learner, the fear occurs in a situation where students have to speak in front of familiar audience. Students concern about the opinion from important people in their life, such as teachers, parents, or their friends.

Many studies agree that fear of doing badly during presentation lead students to be anxious. It can be said that this finding support research done by Liu (2007) explains that fear of negative evaluation is the anxiety associated with the learners' perception of how their familiar audience may negatively view their language ability. In this case, the participants tend to focus on their friends. Their classmates' opinion seems to have sharp negative effects on students' self-esteem and participation.

The general result regarding sources of anxiety in students' speaking performance revealed that most students tend to be worried in speaking English. As the data from the observation exposed, the students looked anxious in performing public speaking in the classroom. However, they have differences in terms of initial or stimulating factors. In short, those language anxieties happened on learning English speaking and it causes selfdefeating effects on students' learning motivation and level of participation.

\section{THE PROCESS OF EXPRESSIVE WRITING IN MINIMIZING STUDENTS' PUBLIC SPEAKING ANXIETY}

This section focuses on the process of expressive writing in order to answer second research question. In conducting the observation, the researcher applies field notes to know the implementation of expressive writing during the teaching learning process for six meetings: April 21 to May 26, 2015. The procedures of expressive writing in this study, refer to Pearson \& Wilson (2008), Malchiodi (2007) and Thompson (in Bolton, 2011) as follow in table 1 .

Each session of expressive writing exercise was followed by discussion and giving feedback. Fortunately, all of the participants were willing to share their writing. They shared their own suggestions for their own selves; moreover, the suggestions can be applied for others. The four participants actively gave suggestions to each other to cope those situations.

During the expressive writing process the students actively involved in their effort to decrease their English speaking anxiety. The sessions of expressive writing seem become a trigger for them to know their own limitation, raise their confidence in finding the solution for their problems, and adjusting to tense situations. This finding is in line with a study conducted by Gorelick, in Malchiodi (2007). He claims that expressive writing is a guided writing exercise designed privately to develop creativity and self-confidence; and improve problem solving and individual adaptive skill.

TABLE I. FIELD NOTES FOR SIX MEETING

\begin{tabular}{|c|c|c|}
\hline $\begin{array}{l}\text { Session } 1 \\
45^{\prime}\end{array}$ & $\begin{array}{l}\text { Joining and } \\
\text { rapport-building }\end{array}$ & $\begin{array}{l}\text { Introducing the expressive writing } \\
\text { (process and functions) and building } \\
\text { positive bond between participants } \\
\text { and researcher. }\end{array}$ \\
\hline $\begin{array}{l}\text { Session } 2 \\
30\end{array}$ & $\begin{array}{l}\text { Developing self- } \\
\text { awareness }\end{array}$ & $\begin{array}{l}\text { Developing self-awareness related to } \\
\text { their EFL competence, and their } \\
\text { main problem in public speaking }\end{array}$ \\
\hline $\begin{array}{l}\text { Session } 3 \\
30\end{array}$ & \multirow[t]{2}{*}{$\begin{array}{l}\text { Focusing } \\
\text { emotional } \\
\text { processes } \\
\text { integration }\end{array}$} & $\begin{array}{l}\text { Developing students' capability in } \\
\text { being open-minded towards negative } \\
\text { emotions while speaking in public } \\
\text { (based on their own experience) }\end{array}$ \\
\hline $\begin{array}{l}\text { Session } 4 \\
30\end{array}$ & & $\begin{array}{l}\text { Students are aware about their } \\
\text { feeling while speaking in public and } \\
\text { the reasons why they feel so }\end{array}$ \\
\hline $\begin{array}{l}\text { Session } 5 \\
30\end{array}$ & & $\begin{array}{l}\text { Developing students' capability to } \\
\text { switch negative } \\
\text { emotions/feelings while speaking in } \\
\text { public into others' feeling }\end{array}$ \\
\hline $\begin{array}{l}\text { Session } 6 \\
30\end{array}$ & $\begin{array}{lr}\text { Reflection } & \text { on } \\
\text { self-care and } \\
\text { possible post- } \\
\text { session } \\
\text { homework }\end{array}$ & $\begin{array}{l}\text { Developing students' capability to } \\
\text { integrate feeling into mind. }\end{array}$ \\
\hline
\end{tabular}

\section{THE BENEFITS AND CHALLENGES FOR STUDENTS IN DOING EXPRESSIVE WRITING FOR THEIR SPEAKING PERFORMANCE.}

Based on the interview, observation, and document analysis, it is found several benefits and challenges in doing expressive writing. The expressive writing give positive effect on students' speaking performance, lower level of students' public speaking anxiety, and better emotional management. Each benefit is described below:

\section{Better Speaking Performance}

The goal of teaching speaking skill is communicative efficiency. Learners should be able to make themselves understand in using their current proficiency. They should try to avoid confusion in the message due to the fault of pronunciation, grammar, and vocabulary. Speaking performance, such as speaking in public, has its own difficuties to be done. Many people have a real fear of public speaking. Some people get phobic about it, and dread being up there with everyone paying close attention to them. The fear of doing public speaking may block students to show their actual capability. Moreover, after writing expressively for six sessions, there are significant improvements of students speaking performances.

\section{Lower Level of Public Speaking Anxiety}

The test of anxiety rating scale is used to measure the level of students' anxiety while performing presentation/public speaking. The scale is arranged based on public speaking anxiety components proposed by Hamilton (1959), which further is called HAM-A. The HAM-A rating scale is one of the first rating scales developed to measure the severity of anxiety symptoms, and is still widely used today in both clinical and research settings. Each item is scored on a scale of 0 (not present) 
to 4 (severe), with a total score range of $0-56$, where $<17$ indicates mild severity, 18-24 mild to moderate severity and 25-30 moderate to severe. Moreover, the result of test anxiety level is shown in the table 2.

TABLE II. RESUlt OF TEST ANXIETy LEVEL HAM-A

\begin{tabular}{|c|c|c|}
\hline \multirow{2}{*}{ Participants } & \multicolumn{2}{|c|}{ Anxiety Level } \\
\cline { 2 - 3 } & Before & After \\
\hline P\#1 & 27 & 21 \\
\hline P\#2 & 25 & 18 \\
\hline P\#3 & 54 & 25 \\
\hline P\#4 & 25 & 17 \\
\hline
\end{tabular}

From the table 2, it shows that all of the Participants have lower level of public speaking anxiety after doing several expressive writing activities. Though, the anxiety of doing public speaking still exist in the four participants, they have better mental to manage their emotion. The level of public speaking anxiety of P\#1 and P\#2 after doing expressive writing session indicate mild to moderate severity of public speaking anxiety. Whereas, the level of public speaking anxiety P\#4 shows that he has mild to moderate severity of public speaking anxiety, it means that expressive writing plays a role in improving his self-esteem related to speak EFL in front of audience. In the other hand, the level of public speaking anxiety of $\mathrm{P} \# 3$ shows that she is still in the category of moderate to severe of public speaking anxiety, nevertheless, she has more confidence and better mental to cope her anxiety of being ignored by the audience.

\section{Better Emotional Management}

As one of the alternatives in minimizing students' speaking anxiety, expressive writing shows us the benefits that help the students to have better mental in doing public speaking, especially in emotion management, stress management, and problem solving. This findings support a research study conducted by Miller (2004), who states that expressive writing may help a person to find meaning in a stressful event, to be better in managing emotions, to stop obsessing or brooding about a difficult experience. Moreover, expressive writing also has a great benefit on memorizing process.

\section{The Challenge of Doing Expressive Writing}

On the other hand, regardless of the demonstrated benefits of expressive writing, there are some limitations of expressive writing that are revealed. Most Participants stated clearly that the beginning of the sessions is the toughest part. They have to encourage themselves to keep on during the sessions of expressive writing, although the writer told them they can stop their writing anytime they want. The concern of expressive writing limitation is on the effort at the beginning of the expressive writing sessions. It is already cautioned earlier that the encouragement is really needed to write about something when they feel they are ready to, unless it result a traumatic event too soon, they may re-experience the event rather than process it. The findings also a symptom of negative experiences of the expressive writing included, especially difficulties expressing emotions and resistance to reflection. As stated in Hockemeyer et al (1999); Baikie \& Wilhelm (2005), that when the Participants should be encouraged to write it is for the reason so that the task does not seem too overwhelming.

\section{CONCLUSIONS}

This study examines students' speaking anxiety in EFL context. In particular, the study seeks to find the factors that may cause the speaking anxiety, the process of expressive writing in minimizing the students' speaking anxiety, and the benefits and challenges of expressive writing. There are four factors that might cause the students' speaking anxiety, namely lack of confidence and shyness, lack of vocabulary, fear of failure, and fear of negative evaluation from the audience. Regarding the benefits and challenges of expressive writing in minimizing students speaking anxiety, it is found that expressive writing helps students to have better speaking performance, lower level of public speaking anxiety, and better mental especially in emotion management, stress management, and problem solving. However, it is also found that the students have difficulties in encouraging themselves to keep on writing during the sessions of expressive writing, moreover, students need more efforts at the beginning of the expressive writing sessions.

In line with the topic under discussion, there are three recommendations for further researchers to enhance the richness of aspects related to the speaking anxiety in English classroom. First, since the number of subjects in this study only limited to four participants, the future research would be better to be conducted on a larger scale, so that the study will gain more perspective in broader and various subjects. Second, it is related to the time allocation for conducting the session of expressive writing. The time is quite limited to conduct optimally. The researcher realizes that there must be some other aspects which still need further investigation. Last, the role of the researcher who also acts as the observer becomes the next limitation of this study. Her subjectivity and conceptual bias might have affected the research result. To cover this problem, a teacher's assistant is invited in to act as independent observer and do videotaping the activity in classroom. The researcher also employs multiple source of evidence in data collection that allowed for a triangulation of the information taken from different sources. Those efforts of the researcher are hoped could minimize the limitation of this study.

\section{REFERENCES}

[1] Adrianto, B \& Goddess, R.S (2006). Kecemasan presentasi ditinjau dari keterampilan komunikasi dan kepercayaan diri pada mahasiswa. Abstrak. Retrieved: http://rac.uii.ac.id/server/document/Public/\%20Bhimo\%.pdf [4 May 2014]

[2] Alwasilah, A. (2002). Pokoknya Kualitatif. Dasar-dasar Merancang dan Melakukan Penelitian Kualitatif. Bandung: Pustaka Jaya.

[3] Anwar. (2009). Hubungan Self-Efficacy Dengan Kecemasan Berbicara di Depan Umum Pada Mahasiswa Fakultas Psikologi USU. Medan: USU.

[4] Baikie, K. A. \& Wilhelm, K. (2005). "Emotional and physical health benefits of expressive writing."Advances in Psychiatric Treatment 11. 338-346.

[5] Bolton. (2011). The Therapetic Potensial of Creative Writing: Writing My Self. London: Jesica Kingsley Publisher.

[6] Cubukcu, F. (2007). A study on the correlation between self efficacy and foreign language learning anxiety. Journal of Theory and Practice in Education, 4(1), 148-158. Darling-Hammond, L.

[7] Fikri, H.T. (2012). Pengaruh menulis pengalaman emosional dalam terapi ekspresif terhadap emosi marah pada remaja. Humanitas IX (2), 103-122 
[8] Hamilton. (1959). The assessment of anxiety states by rating. Journal Psychology 1959; 32:50-55. Retrieved: https://pdbp.ninds.nih. gov/assets/crfs/Hamilton\%20Anxiety\%20 Rating\%20Scale\%20 (HAM-A).pdf [January 2015]

[9] Harmer, J. (2004). How to teach English: an introduction to the practice of English language teaching. London: Longman.

[10] Juhana. (2010). Students' Difficulties in Speaking Class. UPI: Unpublished Thesis

[11] Katz. (2000). Public Speaking Anxiety. University Of Tennessee AT MARTIN Counseling Center.

[12] Lengkanawati, N. S. (2004). "How learners from different cultural backgrounds learn a foreign language". Asian EFL Journal. 6. [Online]. Retrieved: http://asian-efl-journal.com/quarterlyjournal/2004/03/30/how-learners-from-different-culturalbackgrounds-learn-a-foreign-language/\#thethe-tabs-1-4. [March, 2014]

[13] Liu, M. (2007). Anxiety in Oral English Classroom: a Case Study in China. Indonesian Journal of English Language Teaching. Vol 3: P. $119-134$

[14] Malchiodi. (2007). Expressive Therapies : history, theory, and practice. New York: Guilford Publication

[15] McCroskey. (1989). Oral communication apprehension: A summary of recent theory and research. Human Communication Research, 4, 78-96.

[16] Merriam, S. B. (1998). Qualitative Research and Case Study Application in Education. San Fransisco: Josses - Bass Inc.

[17] Nunan, D. (1991). Languange Teaching Methodology: a Textbook for Teacher. London: Prentice Hall.

[18] Pearson, M \& Wilson. (2008). "Using Expressive Counseling Tools to Enhance Emotional Literacy, Emotional Wellbeing and Resilience: Improving Therapeutic Outcomes with Expressive Therapies". Journal of Counselling, Psychotheraphy, and Health. 4(1), 1-19.

[19] Pennebaker, J. W, \& Chung, C. K. (2011). Expressive writing: Connections to physical and mental health. The Oxford handbook of health psychology, 417-437.

[20] Putra, C. D. (2004). Performing Public Speaking Skill: A Case Study of Six Students of Vocational High School of Telecomunication in Banjarbaru South Kalimantan. Bandung: UPI Library (unpublished).

[21] Qonitatin, Novi; Widyawati, Sri; \& Asih, Gusti Semarang. (2011). Pengaruh katarsis dalam Soegijapranata menulis ekspresif sebagai intervensi depresi ringan pada mahasiswa. Jurnal Psikologi Universitas on Diponegoro . 9(1), 21-32

[22] Ratnasari, D (2009). Hubungan antara Kepercayaan Diri dengan Keterampilan Komunikasi Interpersonal Siswa SMA Negeri 1 Srengat Blitar. Malang : Skripsi UNM - Bimbingan Konseling dan Psikologi.

[23] Richards, Jack. (2008). Teaching Listening and Speaking from Theory to Practice. NY: University Press

[24] Sanousi. (2004). The Psychological Role of Expressive and Literary Writing - A Case Study on Kuwaiti Women. Online Journal of Pycological Study of Arts. Retrieved: Error! Hyperlink reference not valid.. [12 Dec 2014].

[25] Scot, D \& Usher, R. (2011). Researching Education: Data Methods and Theory in Educational Inquiry. London: Continuum International.

[26] Sugiyono. (2010). Metode Penelitian Pendidikan: Pendekatan Kualitatif, Kuantitatif, dan R \& D. Bandung: Alfabeta.

[27] Sukmadinata, N. S. (2011). Metode Penelitian pendidikan. Bandung: Remaja Rosda Karya.

[28] Susanti. (2013). "Pengaruh Ekspressive Writing Therapy terhadap Penurunan Tingkat Kecemasan Berbicara di Muka Umum pada Mahasiswa”. Jurnal Psikologi, Volume 9 Nomor 2, Desember 2013. [online]. Retrieved: http://ejournal.uinsuska.ac.id/index.php/psikologi/article/view/174. [June, 2014].

[29] Susilowati, Theresia Genduk. (2009). Pengaruh terapi menulis pengalaman emosional terhadap penurunan depresi pada mahasiswa tahun pertama. Tesis. Yogyakarta : Fakultas Psikologi Universitas Gadjah Mada

[30] Thornbury, S. (2005). How to Teach Speaking. Essex: Longman Pearson Education Limited.
[31] Togatorop, E. (2009). Students' Obstacles in Practicing Speaking English, a Case Study at Batam Polytechnic. Bandung: UPI Library (unpublished).

[32] Warliah, E. (2004). Students' Reluctance to Raise Question in the Classroom, a Case Study at SMUN 8 Bandung. Bandung: UPI Library (unpublished)

[33] Widiati, U. \& Cahyono, B. Y. (2006). "The teaching of EFL speaking in the Indonesian Context: the State of the Art". Jurnal Bahasa dan Seni, tahun 34, nomor 2, pp. 269-292. [Online]. Retrieved: http://sastra.um.ac.id/wp-content/uploads/2009/10/TheTeaching-of-EFL-Speaking-in-the-Indonesian-Context-The-Stateof-the-Art-Utami-Widiati-Bambang-Yudi-Cahyono.pdf. [April, 2014] 